Ann. Biol. anim. Bioch. Biophys., I97I, 11 (3), 47I-487.

\title{
ÉTUDE D'UNE ARN POLYMÉRASE EXTRAITE DE CELLULES INFECTEES \\ PAR LE VIRUS DE LA FIÈVRE APHTEUSE AVANT ET APRÈS SÉPARATION DU MODÈLE
}

\author{
J.-F, DELAGNEAU \\ Station de Virologie et d'Immunologie, I. N. R. A., \\ 78 - Thiverval-Grignon \\ Laboratoire de Virologie végétale, \\ Centre national de Recherches agronomiques, I, N. R. A., \\ 78 - Versailles \\ RÉSUMÉ
}

L'ARN polymérase induite dans les cellules BHK 21 au cours de l'infection par le virus de la fièvre aphteuse a été extraite sous forme de complexes liés à l'ARN viral. Cette préparation catalyse la synthèse d'un $\mathrm{ARN}{ }_{37} \mathrm{~S}$, en présence des 4 nucléotides et des ions $\mathrm{Mg}^{++}$. A partir des complexes de replication, l'enzyme a été purifiée sous une forme dépendante de l'ARN viral. Cette enzyme incubée en présence de divers ARN n'est stimulée que par son ARN homologue, de plus en l'absence des nucléotides, elle ne paraît capable de se fixer que sur l'ARN viral, et non sur les ARN cellulaires totaux.

\section{INTRODUCTION}

Dès I962, les expériences réalisées par Dor et SPIEGELMAN, COOPER et ZINDER, suggéraient que les virus à $A R N$ induisaient dans la cellule hôte un système enzymatique pouvant synthétiser directement un acide ribonucléique viral à partir d'un modèle qui est lui-même cet $A R N$ viral.

L'étape suivante devait être l'identification, puis l'isolement de cette enzyme (réplicase ou ARN polymérase virale) à partir des cellules bactériennes infectées par le phage (Haruna et Spiegelman, r963; August et al., rg63; Weissman et al., I963). Grâce à la grande pureté des préparations obtenues, il a été possible d'étudier en détail les propriétés de l'enzyme notamment la spécificité vis-à-vis de divers modèles d'ARN. 
Dans les systèmes virus cellules animales ou cellules végétales les difficultés techniques inhérentes à la qualité et à la quantité du matériel disponible, n'ont pas permis un développement si rapide des connaissances. Cependant plusieurs équipes ont obtenu des préparations enzymatiques reconnaissant le génome viral (AsTIER et CoRnuet, I969; WATSON et al., I969; GaRIGLIANo et al., I970). Nous-mêmes à partir de cellules $B H K 2 I$, infectées par le virus de la fièvre aphteuse avons caractérisé une protéine enzymatique, partiellement purifiée, vraisemblablement d'origine virale, capable de réaliser in vitro la synthèse de ribopolynucléotides sous la dépendance de l'ARN viral.

Dans un premier temps, nous avons isolé le système de replication à partir de cellules infectées puis caractérisé son activité afin de vérifier que le matériel isolé était bien d'origine virale. Dans un deuxième temps nous nous sommes efforcé de séparer la protéine enzymatique de l'ARN et de tester son activité en présence de différents modèles d'ARN.

\section{MATÉRIEL, E'T MÉTHODES}

$$
\text { A. - Matériel }
$$

I. Virus.

Le virus utilisé est un mutant du virus de la fièvre aphteuse de type antigénique $O$, obtenu par sélection et clonage en culture cellulaire à basse température (Asso, 1967). Ce mutant n'est plus pathogène ; il permet de travailler sans précautions excessives. Le virus est conservé congelé en présence de glutamate de $\mathrm{Na}\left(0,5 \mathrm{p}\right.$. I0O) à $-20^{\circ} \mathrm{C}$.

2. ARN.

L'ARN viral est extrait par le phénol froid à partir de suspension virale concentrée au Polyéthylène glycol (PEG) ; il est purifié par ultracentrifugation en gradient de saccharose $(5-20 \mathrm{p}$. Ioo). Les $A R N$ des virus $R_{17}$, et de la mosaïque jaune du navet ont été préparés de la même manière. Les polynucléotides synthétiques ont été gracieusement fournis par Mme GrunBerGManago.

\section{Cellules.}

Les cellules BHK 2I (lignées de cellules de rein de hamster) sont utilisées aussi bien pour la production des stocks de virus que pour la préparation des extraits enzymatiques. Des couches monocellulaires de rein de porc (F) (HAAG et al., I962) sont utilisées de préférence aux cellules BHK pour les titrages d'infectiosité (ARN et virus), les plages obtenues étant plus aisément détectables.

\section{Produits chimiques.}

Le saccharose utilisé (débarrassé de toute trace de RNase) est obtenu chez Mann Research Laboratories, New York. Les ribonucléosides-triphosphates sont obtenus chez Calbiochem, Los Angeles; les ribonucléosides triphosphates ( $U$ ou $G$ ) marqués au ${ }^{32} P$ en position $\alpha$ sont préparés par le C. E. A. La créatine kinase, la phosphocréatine (sel de potassium) sont des produits de chez Worthington Biochemicals. Les autres composés chimiques classiques utilisés au cours des expériences sont ou bien des produits recristallisés, ou bien des produits " enzyme grade ».

$$
\text { B. - Méthodes }
$$

\section{Préparation des cellules infectées.}

Environ IO $^{9}$ cellules BHK $2 \mathrm{I}$ sont infectées à une multiplicité d'infection de 30 à 50 unités formant des plages (UFP) par cellule. L'incubation est réalisée à $3^{\circ} \mathrm{C}$, on suit la synthèse d'ARN 
par l'étude de l'incorporation d'uridine tritiée $(0,5 \mu \mathrm{Ci} / \mathrm{ml})$ sur des aliquotes en présence d'actinomycine $\mathrm{D}(5 \mu \mathrm{g} / \mathrm{ml})$. Lorsque le taux de synthèse de l'ARN viral est maximum (3 heures 30 après l'infection) (fig. I), les cellules sont lavées trois fois dans un milieu salin isotonique à $4^{\circ} \mathrm{C}$. Les lavages éliminent tous les produits de dégradation du milieu d'incubation.
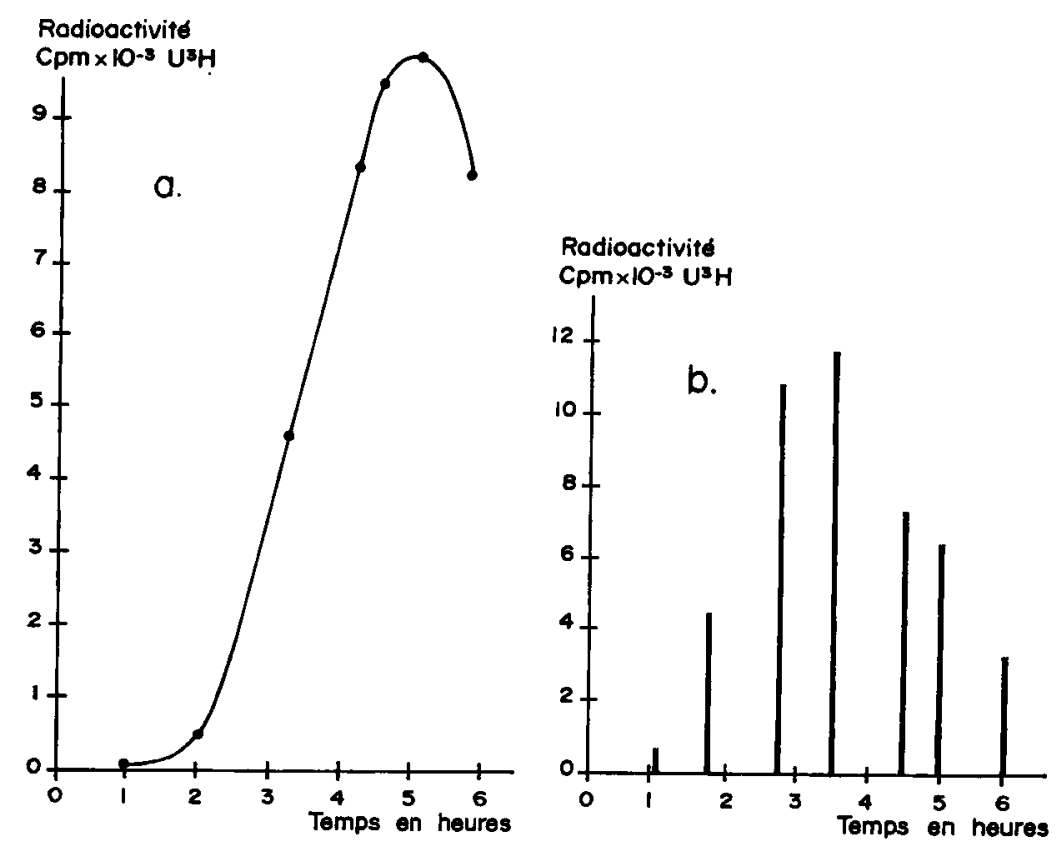

FIG. I. - a) Courbe de gauche : synthèse d'ARN viral étudiée en marquage continu, le marqueur est ajoute au temps $0 \quad\left(0,5 \mu \mathrm{Ci}\right.$ d'uridine $\left.{ }^{3} \mathrm{H} / \mathrm{ml}\right)$

b) Courbe de droite : synthèse d'ARN viral étudiée par marquage bref

Les cellules sont infectées en milieu froid. Les marquages sont réalisés sur des aliquots ( $10 \mathrm{Ci} / \mathrm{ml}$ pendant ro $\mathrm{mn}$ )

\section{Préparation des extraits cytoplasmiques.}

Les cellules lavées sont alors lysées par mise en suspension dans un tampon hypotonique (Penman, 1964) (tris-HCl $\mathrm{Io}^{-2} \mathrm{M}, \mathrm{pH} 7,4, \mathrm{MgCl}_{2} \mathrm{I}, 5 \times \mathrm{Io}^{-3} \mathrm{M}, \mathrm{KCl} \mathrm{Io}^{-3} \mathrm{M}$ ). Au bout de Io $\mathrm{mn}$, un léger broyage mécanique à l'homogénéiseur Potter termine la destruction cellulaire. On obtient un extrait cytoplasmique en eliminant les noyaux par une centrifugation de ro mn à $600 \mathrm{~g}$.

\section{Mesure de l'activité enzymatique in vitro.}

On mesure l'incorporation, dans un produit acido-insoluble, de ribonucléosides triphosphates marqués par le $\mathrm{P}^{32}$ en position $\alpha$. Le mélange réactionnel contient dans un volume final de $\mathrm{I} \mathrm{ml}$ : tris- $\mathrm{HCl}$ o, I millimole $\mathrm{pH} 8, \mathrm{I}$, acétate de $\mathrm{Mg}$ I 8 micromoles, phosphocréatine $\mathrm{I}, 5$ milligrammes, créatine-kinase 0,2 milligrammes, actinomycine $D 5$ microgrammes, nucléotides non radioactifs $A, C, G$ ou $U$ o,4 micromoles, et enfin nucléotides marqués au $P^{82}$ ( $U$ ou $G$ ) 0,1 micromoles. A $50 \mu l$ de milieu standard sont ajoutés $20 \mu l$ d'extrait enzymatique que l'on incube pendant des temps variables. Les incubations sont terminées par congélation brutale. Pour déterminer la radioactivité incorporée dans la fraction acido-insoluble, on ajoute dans chaque essai $0,3 \mathrm{ml}$ de pyrophosphate de sodium saturé, $1,6 \mathrm{mg}$ d'ARN et $0,06 \mathrm{mg}$ de sérum albumine bovine (solution entraîneur) et $3 \mathrm{ml}$ d'une solution d'acide trichloracétique à $5 \mathrm{p}$. Ioo (TCA) (additionnée de pyrophosphate de $\mathrm{Na}$ à ro $\mathrm{g} / \mathrm{l}$ ). Après ro $\mathrm{mn}$ à $\mathrm{o}^{\circ} \mathrm{C}$, le précipité est lavé sur filtre de verre (Whatman $\mathrm{GF} / \mathrm{C}$ ) avec environ $50 \mathrm{ml}$ de $\mathrm{TCA}$ à $4^{\circ} \mathrm{C}$, puis avec $6 \mathrm{ml}$ d'alcool. La radioactivité des échantillons est mesurée dans un compteur Beckman à scintillation. 
4. Analyse du produit synthétisé par l'ARN polymérase.

Les extractions des ARN synthétisés in vitro par les préparations de polymérase sont conduites suivant la méthode Phénol-SDS (GIRARD, I968) si ce n'est que l'opération se fait à température ambiante pour éviter la fusion des structures bicaténaires. L'ARN contenu dans la phase aqueuse ajustée à $0,2 \mathrm{M}$ de $\mathrm{NaCl}$ est précipité par 2 volumes d'éthanol à $-20^{\circ} \mathrm{C}$ en présence d'ARN non radioactif entraîneur.

Après précipitation le matériel est analysé sur gradient 5-20 p. roo de saccharose (Rotor SW 50,49 ooo $\mathrm{t} / \mathrm{mn}$ pendant 3 heures à $4^{\circ} \mathrm{C}$ ). Les fractions de 3 gouttes collectées par le fond du tube sont précipitées par du TCA à 5 p. roo et traitées en vue de la détermination de la radioactivité.

\section{Processus chromatographique.}

a) Gel-filtration sur colonne d'agarose $50 \mathrm{M}$ (Bio. rad.).

Est utilisée pour la préparation des complexes de replication (BALTIMORE, I966).

b) Gel-filtration sur colonne d'agarose 1,5 M (Bio. rad. 200-400 mesh).

Est mise en ouvre dans le but de séparer l'ARN de la protéine enzymatique (Astier et CORNuEt, 1969).

Dans les deux cas, l'agarose est lavée soigneusement 3 fois à l'eau distillée et une quatrième fois avec le tampon, puis dégazée sous vide. Les colonnes ne sont jamais utilisées immédiatement. Toutes les chromatographies ont lieu à la chambre froide. Les fractions sont collectées automatiquement et repérées par mesure de l'absorption à $280 \mathrm{~nm}$.

\section{Mesure de la quantité de protéine.}

Elle est effectuée par la méthode LowRY, Rosebrough, FARR (195I) ; la gamme étalon a été établie à l'aide d'albumine bovine.

\section{RÉSULTATS}

\section{A. - Isolement des complexes de replication et caractérisation de leur activité}

\section{Obtention par ultracentrifugation d'une préparation brute.}

Les travaux de Penman, Becker et Darneli, montraient dés Ig64 que la structure cytoplasmique présentant l'activité ARN polymérase virale était sensible à l'action du déoxycholate de sodium. Eñ d'autres termes cela veut dire que l'enzyme qui nous intéresse est liée aux membranes intracytoplasmiques. Polatnick et ARLINGHAUS, dès I 967 avaient réussi à sédimenter par ultracentrifugation les structures membranaires actives contenues dans le cytoplasme des cellules BHK infectées par le virus de la fièvre aphteuse. Nous avons conservé cette première étape dans notre travail. Une ultracentrifugation ( $120000 \mathrm{~g} / 45 \mathrm{mn}$, Rotor $\mathrm{R}$ 50, Spinco $\mathrm{L}$ 2) permet de récolter $90 \mathrm{p}$. roo de l'activité contenue dans les extraits cytoplasmiques. Cette opération, non seulement est une excellente concentration de notre matériel, mais est aussi un début de purification, car nous éliminons les protéines légères. Les culots obtenus à partir de Ioo $\mathrm{ml}$ d'extrait cytoplasmique sont repris avec précaution à la pipette et remis en suspension dans du tampon (volume final ro $\mathrm{ml}$ ) (GrRARD, I969) (0,05 M tris- $\mathrm{HCl}, \mathrm{pH} 7,5,0,005 \mathrm{M}$ acétate de magnésium, 0,005 M $\beta$-mercaptoéthanol, o,oor M EDTA 20 p. roo de glycérol). Cette préparation enzymatique appelée "préparation brute " contient entre 25 et $30 \mathrm{mg}$ de protéine par 
$\mathrm{ml}$; elle peut être conservée pendant plusieurs semaines au congélateur sans perte d'activité.

2. Traitement par les détergents: solubilisation de l'activité enzymatique (tab1. I).

Pour purifier l'enzyme nous avons décidé de la séparer des membranes sur lesquelles elle est fixée. Or des mesures réalisées directement sur la préparation

TABLEAU I

Solubilisation de l'activité enzymatique

\begin{tabular}{c|c|c|c}
\hline \hline & \multicolumn{3}{|c}{ Radioactivité incorporée } \\
\cline { 2 - 3 } Traitement & $\begin{array}{c}\text { C.p.m. } \\
\text { après 2,5 mn } \\
\text { d'incubation }\end{array}$ & $\begin{array}{c}\text { C.p.m. } \\
\text { après 5 mn } \\
\text { d'incubation }\end{array}$ & $\begin{array}{c}\text { C.p.m. } \\
\text { après } 10 \mathrm{mn} \\
\text { d'incubation }\end{array}$ \\
\hline $\begin{array}{c}\text { Activité de l'extrait brut } \\
\text { Activité résiduelle } \\
\text { après le traitement } \\
\text { au détergent }\end{array}$ & 1724 & 2609 & 5881 \\
$\begin{array}{c}\text { Activité résiduelle } \\
\text { après une dialyse de 24 } \\
\text { Activité non solubilisée } \\
\text { culot (10 000 g/10 mn) }\end{array}$ & 1183 & 1475 & 2216 \\
\hline \hline
\end{tabular}

" brute " montrent que l'activité de l'enzyme est rapidement affectée par des concentrations croissantes de déoxycholate de $\mathrm{Na}$ (DOC). Ainsi à $0,5 \mathrm{p}$. Ioo l'incorporation des nucléotides décroît de 40 à $60 \mathrm{p}$. Ioo par rapport à un échantillon témoin incubé pendant ro $\mathrm{mn}$ bien que la dose ne soit pas suffisante pour apporter une solubilisation totale.

En conséquence, nous avons recherché un traitement plus efficace, mais affectant le moins possible l'activité de l'enzyme. Le traitement faisant intervenir I p. Ioo de Brij 58,0,5 p. roo de DOC (détergent non ionique - détergent ionique) entraîne une destruction totale des structures lipidiques ; l'activité enzymatique ne sédimente plus lors d'une centrifugation à Io $000 \mathrm{~g}$ pendant Io $\mathrm{mn}$. La perte d'activité s'élève à $60 \mathrm{p}$. Ioo par rapport à l'activité avant le traitement (cf. tabl. I). Une action directe des détergents au niveau de la molécule est peu probable puisqu'une dialyse de 24 heures de "l'enzyme solubilisée " contre le tampon ne restaure pas l'activité initiale (tabl. I).

\section{Caractérisation de l'activité enzymatique "soluble " (cf. tabl. 2).}

a) L'enzyme étudiée reste liée aux molécules d'ARN endogènes (matrices) même après la solubilisation par les détergents, puisque l'incorporation des nucléotides se réalise sans addition d'ARN viral exogène au milieu d'incubation (tabl. 2).

L'activité étudiée est donc celle des complexes de replication. La taille de cet 
ensemble de molécules (enzyme, ARN viral, ARN en cours de synthèse) peut être estimée par gel filtration. Le repérage de l'activité enzymatique est effectué simplement par un marquage interne de ce complexe : on incube la préparation en milieu.

TABLEAU 2

Caractérisation de l'activité enzymatique

\begin{tabular}{|c|c|c|}
\hline Conditions des tests & C.p.m. $/ 0,05 \mathrm{ml}$ enzyme $/ 10 \mathrm{r}$ & \\
\hline 1. Retrait de nucléotides & $\begin{array}{l}\text { Milieu complet A UGC } \\
\text { Milieu incomplet }- \text { GTP } \\
-\quad-\quad-\text { ATP }\end{array}$ & $\begin{array}{r}2607 \\
236 \\
395\end{array}$ \\
\hline 2. Action de l'actinomycine $\mathrm{D}$ & $\begin{array}{c}0 \mu \mathrm{g} / \mathrm{ml} \\
5 \stackrel{-}{10}- \\
50-\end{array}$ & $\begin{array}{ll}2 & 216 \\
2 & 108 \\
2 & 152 \\
1 & 936\end{array}$ \\
\hline 3. Addition d'ARN matrice $37 \mathrm{~S}$ & $\begin{aligned} & 0 \text { ARN } \\
+ & 4 \mu \mathrm{g} \mathrm{ARN}\end{aligned}$ & $\begin{array}{l}3639 \\
3574\end{array}$ \\
\hline 4. Effet des ions $\mathrm{Mg}^{++}$ & $\begin{array}{l}\text { Milieu complet : } 18 \mathrm{mM} \mathrm{Mg}^{++} \\
\text {Milieu sans } \mathrm{Mg}^{++}\end{array}$ & $\begin{array}{r}3943 \\
226\end{array}$ \\
\hline
\end{tabular}

radioactif pendant $2 \mathrm{mn}$, les brins d'ARN en cours de synthèse sont marqués, mais non libérés dans le milieu. On constate (fig. 2) qu'une chromatographie réalisée sur agarose $50 \mathrm{M}$ sépare les complexes de replication des autres molécules virales; en effet la radioactivité et l'activité enzymatique sont uniquement localisées au niveau du pic d'exclusion.

b) L'activité enzymatique nécessite la présence des cations $\mathrm{Mg}$. Le retrait d'un seul nucléotide du milieu standard diminue de 90 p. Ioo l'incorporation du traceur radioactif (tabl. 2). Enfin, notre préparation n'est pas sensible à l'addition d'actinomycine D jusqu'à la concentration de $50 \mu \mathrm{g} / \mathrm{ml}$; elle ne contient donc pas d'ARN polymérase DNA dépendante cellulaire.

c) Cinétiques enzymatiques (fig. 3 et 4 ). La vitesse de la réaction est constamment décroissante de o à $15 \mathrm{mn}$, puis la quantité totale de matériel synthétisé diminue sensiblement dès la $20^{\circ} \mathrm{mn}$ (fig. 3). Ce résultat traduit la dégradation des molécules nouvellement synthétisées sous l'action des nucléases. D'autre part, l'enzyme fixée sur son ARN matrice semble uniquement capable de terminer les brins d'ARN en cours de synthèse et non de réaliser de nouvelles initiations in vitro puisque la cinétique d'incorporation des nucléotides s'amortit avec le temps.

La cinétique a été étudiée à différentes températures $\left(30^{\circ}, 36^{\circ}, 39^{\circ}, 42^{\circ} \mathrm{C}\right)$ (fig. 4). La vitesse maximale de synthèse se situe entre $36^{\circ}$ et $39^{\circ} \mathrm{C}$. En deçà de $36^{\circ} \mathrm{C}$ et au-delà de $39^{\circ} \mathrm{C}, l^{\prime}$ 'enzyme est nettement moins active.

d) L'analyse du matériel synthétisé in vitro après Io $\mathrm{mn}$ d'incubation a été réalisée, après déprotéination (extraction des acides nucléiques au phénol-SDS), sur gradient linéaire de concentration de saccharose (5-20 p. roo). L'ARN synthétisé 
Rodiooctivité

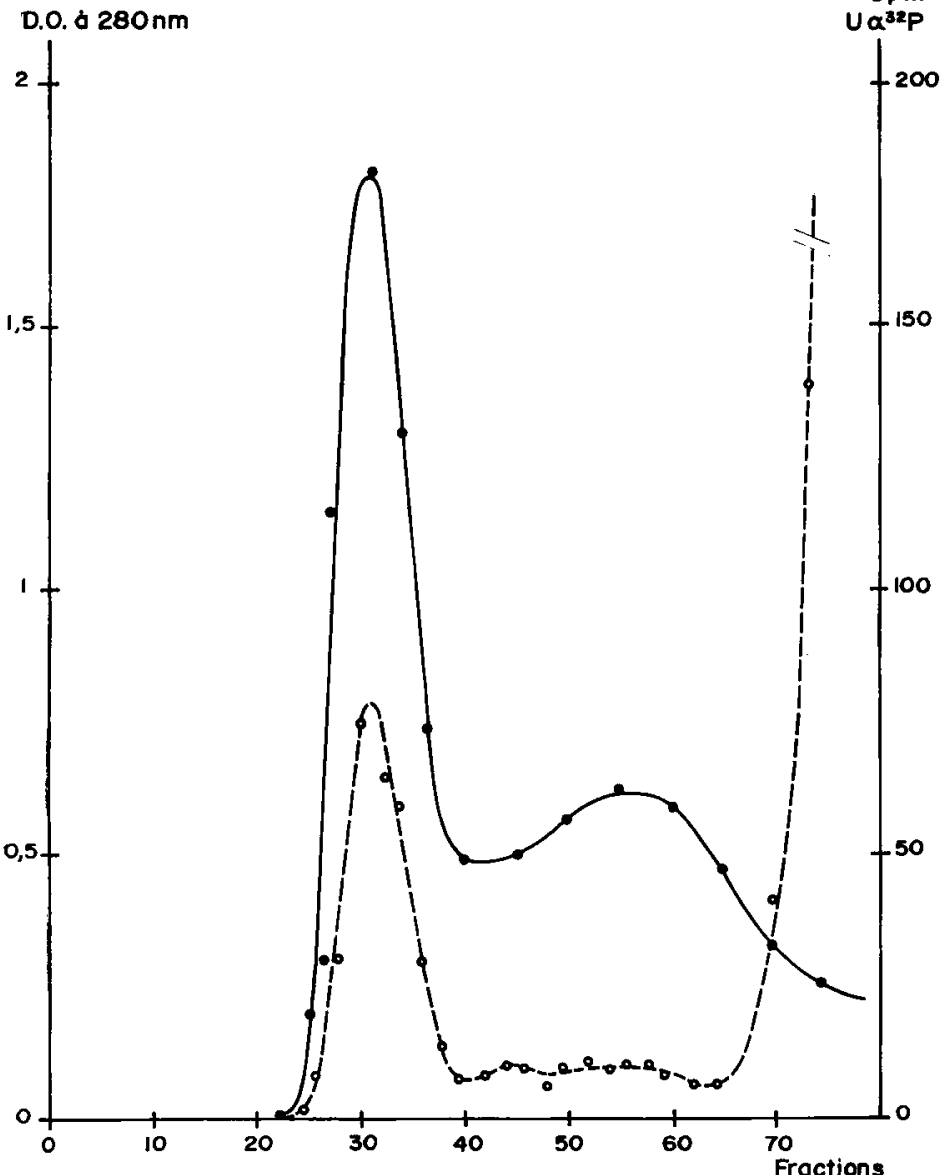

FIG. 2. - Chromatographie d'exclusion sur Agarose $50 M$ (Baltimore, 1966) de la préparation après action des détergents

- - - - densité optique à $280 \mathrm{~nm}$

...

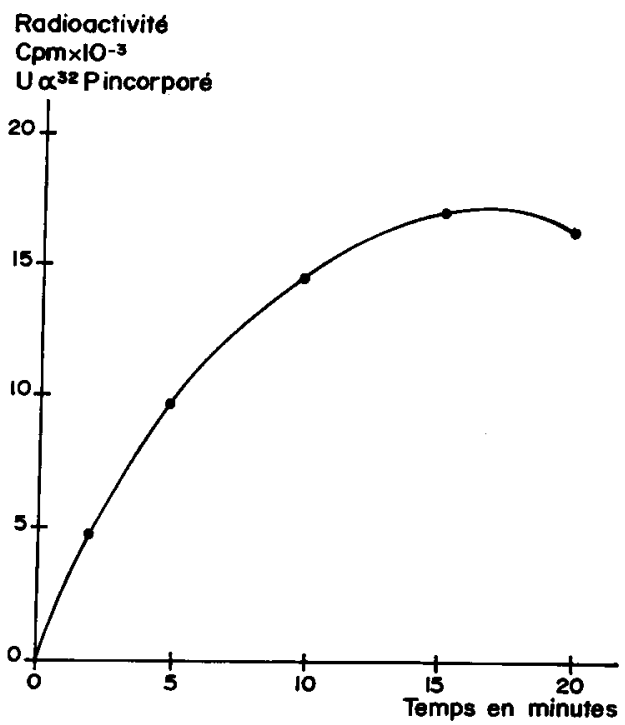

FIG. 3. - Cinétique de l'incorporation de nucleotides par les complexes de replication à $36^{\circ} \mathrm{C}$ Chaque poirit correspond à l'incubation de $0,02 \mathrm{ml}$ d'enzyme dans $0, I \mathrm{ml}$ de milieu 


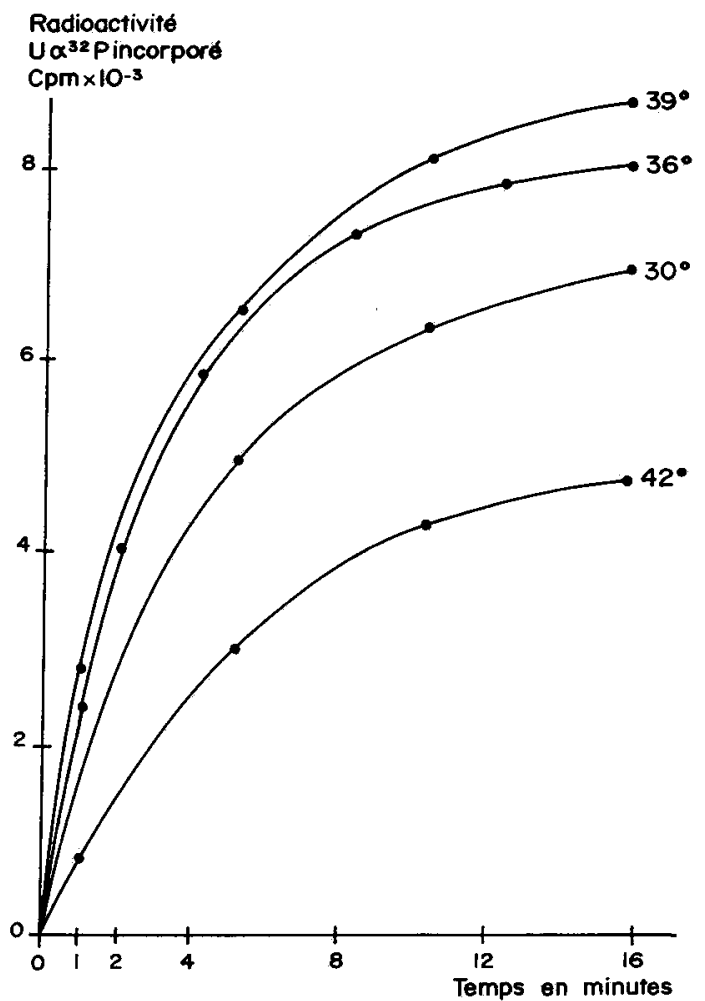

FIG. 4. - Études cinêtiques à $30^{\circ}, 36^{\circ}, 39^{\circ}, 42^{\circ} \mathrm{C}$ de l'incorporation de nucléotides par les complexes de replication

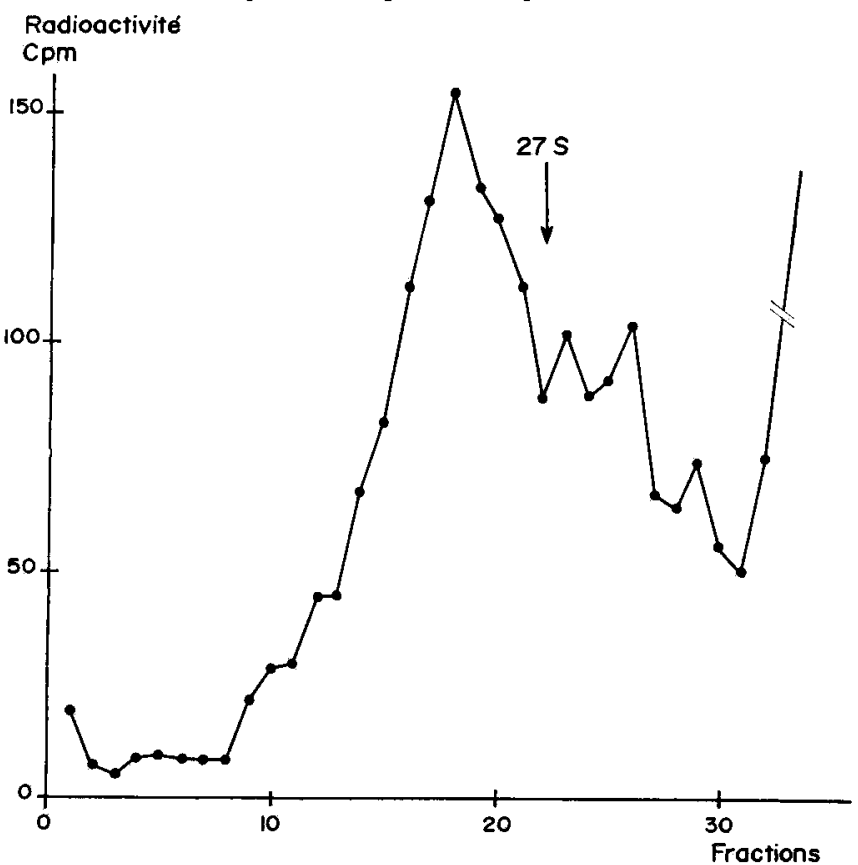

FIG. 5. - Analyse sur gradient de saccharose de l'ARN viral synthétisé in vitro $0, \mathrm{~m} \mathrm{ml}$ d'enzyme sont incubés pendant to $\mathrm{mn}$

L'extrait phénolique est analysé sur gradient 5-20 p. roo de saccharose

L'ARN du virus de la mosaĩque jaune du navet (VMJN) est placé sur un gradient préparé dans les mêmes conditions et nous sert de marqueur interne 
se répartit en deux classes, la première sédimente aux environs de $37 \mathrm{~S}$ et correspondrait à 1'ARN viral, la deuxième possède un coefficient de sédimentation plus faible (inférieur à $27 \mathrm{~S}$ ) (cf. fig. 5).

e) Dans les mêmes conditions expérimentales des extraits cytoplasmiques de cellules non infectées ne catalysent aucune incorporation de traceur radioactif dans du matérial acido-insoluble.

\section{B. - Séparation et caractérisation d'une préparation enzymatique sensible à l'ARN du virus de la fièvre aphteuse}

I. Dissociation de l'enzyme et de son modèle.

La dissociation de l'enzyme et de son modèle a été réalisée par des variations de la force ionique et la séparation a été effectuée par chromatographie sur tamis moléculaire. La fraction " enzyme soluble " est ajustée à $0,5 \mathrm{M}$ en sulfate d'ammonium et laissée pend ant Io $\mathrm{mn}$ à $+4^{\circ} \mathrm{C}$. Cinq $\mathrm{ml}$ de cette solution sont déposés au sommet d'une colonne d'agarose $\mathrm{I}, 5 \mathrm{M}(\varnothing=2,5 \mathrm{~cm}, \mathrm{~h}=30 \mathrm{~cm})$ équilibrée en tampon tris- $\mathrm{HCl}$ Io $^{-2} \mathrm{M}, \mathrm{pH} 7,4, \mathrm{Mg} \mathrm{Cl}_{2}$ Io $^{-3} \mathrm{M}, \beta$-mercaptoéthanol o,oo5 $\mathrm{M}$, glycérol $20 \mathrm{p}$. roo.

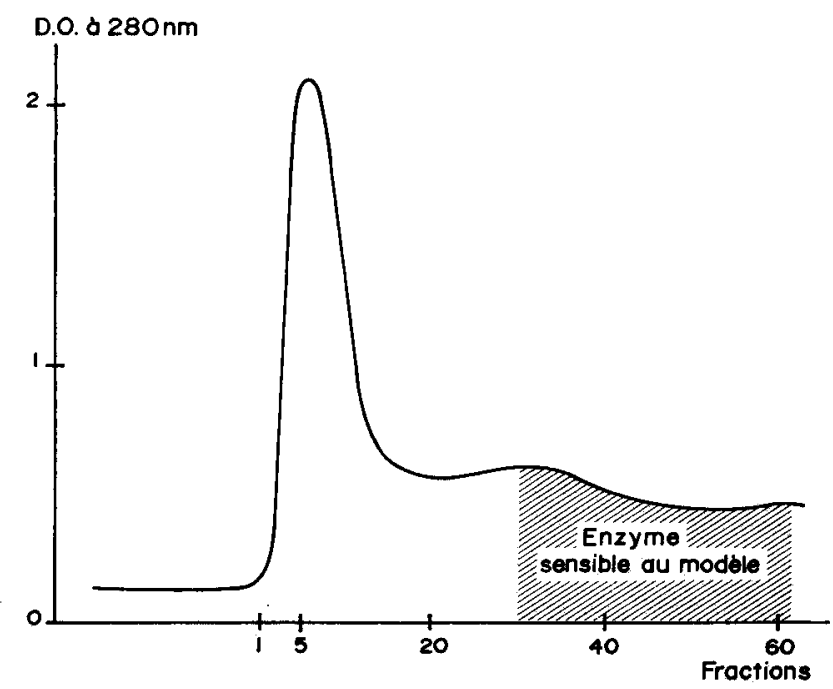

FIG. 6. - Chromatographie de l'enzyme soluble sur Agarose 1,5 M $5 \mathrm{ml}$ d'extrait enzymatique soluble sont portés à $0,5 \mathrm{M}$ en sulfate d’ammonium pendant io $\mathrm{mn}$ à $+4^{\circ} \mathrm{C}$, placés au sommet d'une colonne d'Agarose $\mathrm{I}, 5 \mathrm{M}(\varnothing=2,5 \mathrm{~cm}, \mathrm{~h}=30 \mathrm{~cm})$ et élués en tampon tris- $\mathrm{HCl} \mathrm{IO}^{-2} \mathrm{M}$ pH $7,4, \mathrm{MgCl}_{2} \mathrm{IO}^{-3} \mathrm{M}, \beta$-Mercaptoéthanol o,oo5 $\mathrm{M}$, Glycérol 20 p. Ioo.

La vitesse d'écoulement est de I $2 \mathrm{ml}$ à l'heure. Les fractions sont collectées et la densité optique enregistrée automatiquement à $+4^{\circ} \mathrm{C}$.

L'activité sensible à l'addition de 1'ARN viral (fig. 6) apparaît dans la zone de diffusion libre des molécules. Le pic exclu est très riche en $A R N\left(\frac{D O 260 \mathrm{~nm}}{D O 280 \mathrm{~nm}}\right.$ voisin de 2) tandis que les molécules stuccédant à ce pic présentent un rapport de DO qui se rapproche de $I$. Les fractions intéressantes contiennent moins de o,I mg de protéine/ml, et l'activité enzymatique contenue dans ces fractions est concentrée Io fois par précipitation à $50 \mathrm{p}$. Ioo de saturation de sulfate d'ammonium. 
2. Propriétés de la préparation d'enzyme sensible au modèle.

Comme le montrent les cinétiques enzymatiques (fig. 7), la réaction dépend étroitement de l'addition de l'ARN viral modèle au milieu d'incubation. La cinétique d'incorporation des nucléotides est linéaire puisque la préparation est débarrassée

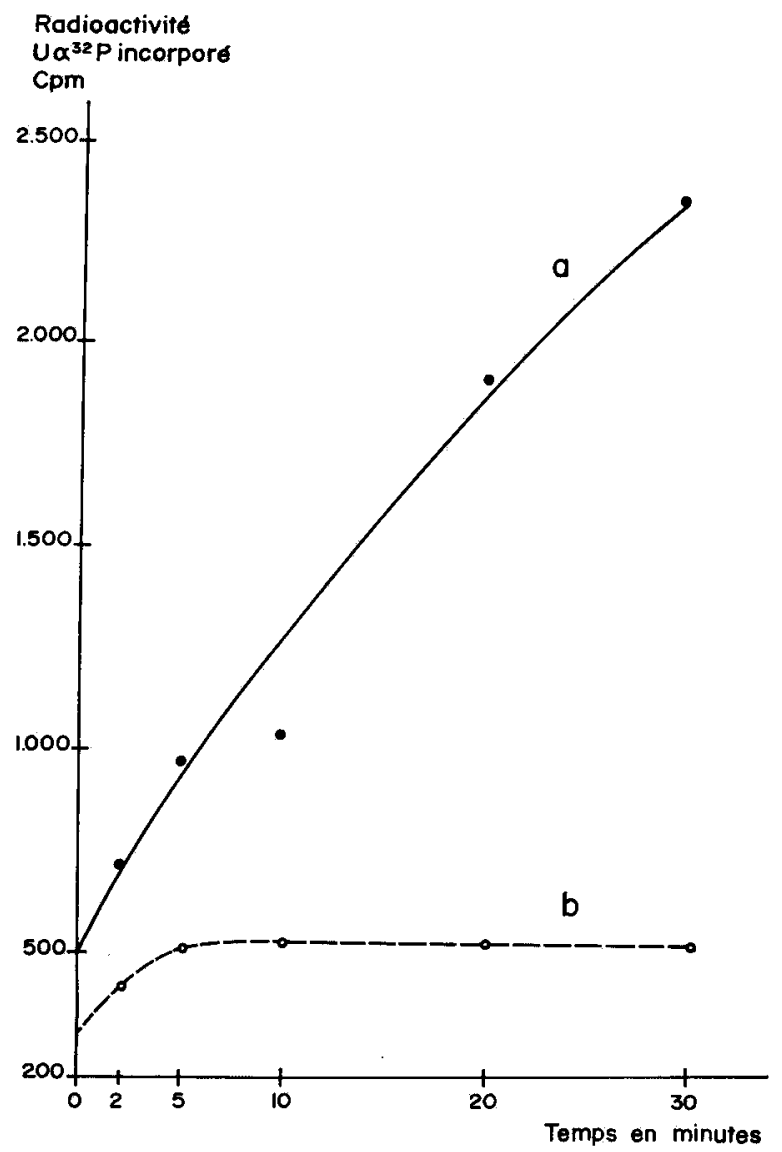

Fig. 7. - Cinétique de la réaction. Le marqueur est UTP ${ }^{32} P(300 \mathrm{mCi} / \mathrm{mM})$

a) A $20 \mu 1$ d'extrait enzymatique on ajoute ro $\mu \mathrm{g}$ d'ARN viral

b) Courbe témoin : $20 \mu 1$ d'extrait enzymatique sans ARN.

des nucléases qui contaminaient l'enzyme soluble. Compte tenu de l'activité spécifique du marqueur au moment de l'expérience $(300 \mathrm{mCi} / \mathrm{mM}$ ) on calcule que I $\mathrm{mg}$ de protéine incorpore $0,3 \mathrm{~m} \mu$ moles d'UTP- $\alpha{ }^{32} \mathrm{P}$ au bout de $30 \mathrm{mn}$ d'incubation.

- La spécificité de l'enzyme a été étudiée vis-à-vis de différentes molécules d'ARN ajoutées comme modèle. L'incorporation des nucléotides est stimulée par le génome du virus de la fièvre aphteuse alors que l'ARN du phage $R_{17}$, du virus de la mosaique jaune du navet, ainsi que les hétéro-polymères synthétiques poly $A G$ et poly $A C$ sont peu ou pas reconnus (cf. tabl. 3 ).

L'activité enregistrée en présence d'ARN est celle d'une ou plusieurs molécules de polymérase liée au modèle viral. Cette structure est certainement plus légère 
ARN POLYMÉRASE DU VIRUS DE LA FIÈVRE APHTEUSE

TABLEAU 3

Spécificité de l'enzyme pour le modèle

\begin{tabular}{c|c}
\hline \hline $\begin{array}{c}\text { Modèle } \\
\text { ajouté au milieu d'incubation } \\
(12 \mu \text { g par essai) }\end{array}$ & $\begin{array}{c}\text { Incorporation } \\
\end{array}$ \\
\cline { 2 - 2 } Absence d'ARN & en c.p.m./20 $\mu$ l enzyme $/ 20 \mathrm{mn}$ \\
ARN-FA & 285 \\
ARN-TYMV & 1514 \\
ARN-R 17 & 324 \\
Poly AG & 401 \\
Poly AC & 307 \\
\hline
\end{tabular}

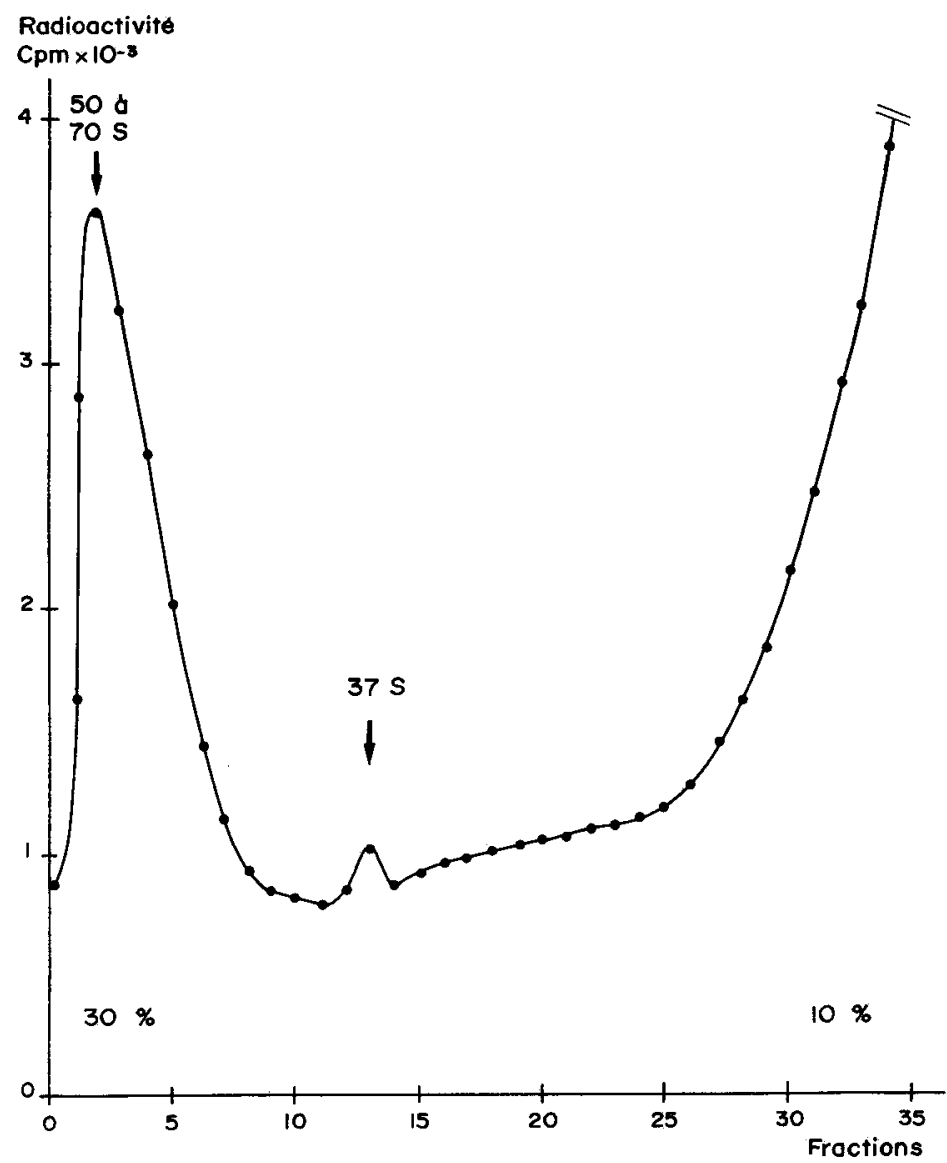

Fig. 8. - Aralyse de l'enzyme fixé à l'ARN après io mn d'incubation

On dépose roo $\mu \mathrm{l}$ d'enzyme incubée ro $\mathrm{mn}$ en présence d'ARN viral, sans déprotéiner, au sommet d'un gradient de saccharose I0-30 p. IOo, centrifugation pendant IIo $\mathrm{mn}$ à $64000 \mathrm{t} / \mathrm{mn}$. La radioactivité de chaque fraction est mesurée après récolte par le fond du tube. L'ARN viral $37 \mathrm{~S}$ déposé sur un gradient identique sert de marqueur. 
que les complexes de replication trouvés dans le cytoplasme des cellules infectées. L'analyse en ultracentrifugation sur gradient de concentration linéaire de saccharose ro-30 p. roo de l'enzyme après une courte incubation en présence d'ARN viral, montre que le matériel actif est situé près du fond du gradient et posséderait un coefficient de sédimentation de $50-70 \mathrm{OS}$ (fig. 8). Ce coefficient est très inférieur à $300 S$, valeur attribuée aux complexes de replication (GIRARD, I968) isolés à partir de cellules Hela infectées par le virus de la poliomyélite.

Après extraction au phénol-SDS des acides nucléiques synthétisés pendant Io mn par l'enzyme incubée en présence de l'ARN viral, on constate que les nucléotides ont été incorporés dans un produit hétérogène ayant un coefficient de sédimentation compris entre $I 8$ et $37 \mathrm{~S}$ (fig. 9). Le produit est entièrement hydrolysé par la RNase après dénaturation par la chaleur.

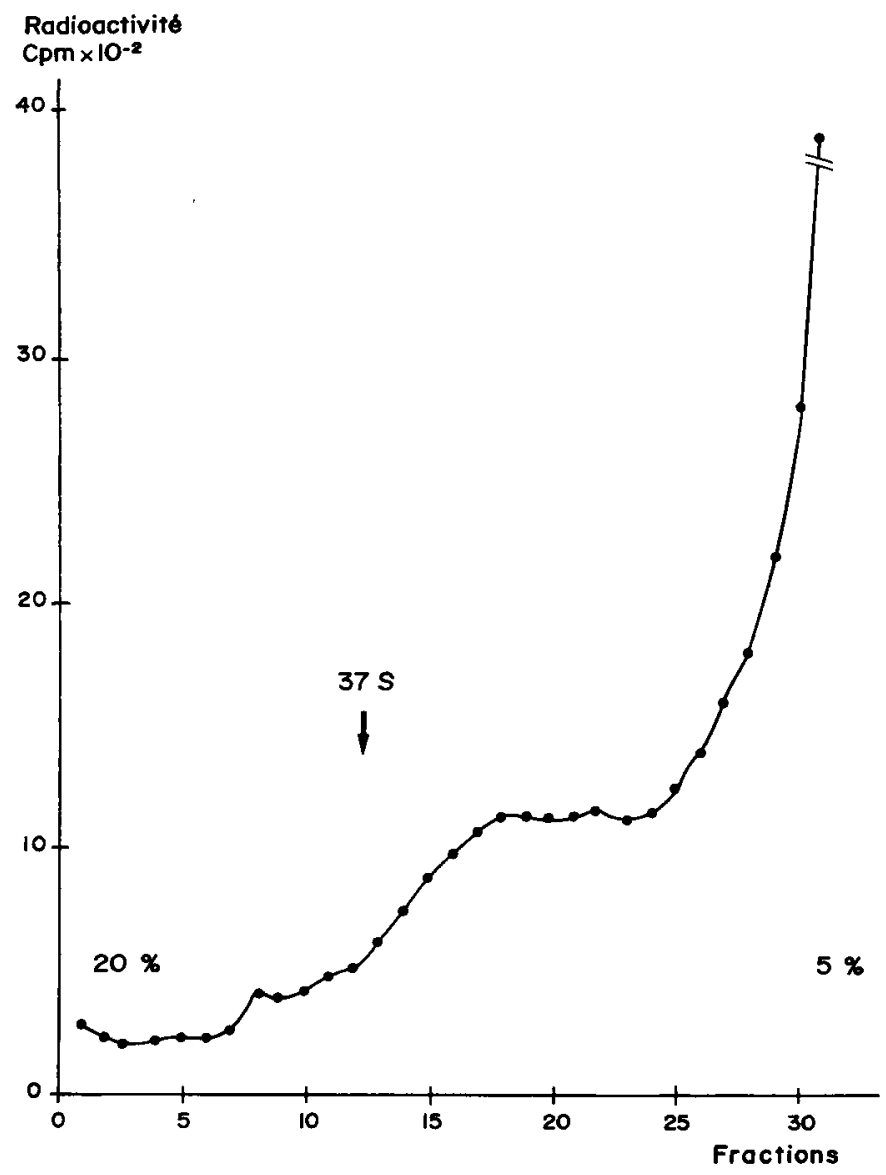

FIG. 9. - Analyse du produit in vitro

Le produit d'une réaction enzymatique de ro mn est extrait au phénol SDS puis centrifugé ro5-1ro mn à $4^{\circ} \mathrm{C}$ à $64000 \mathrm{t} / \mathrm{mn}$ dans un gradient de saccharose 5-20 $\mathrm{p}$. 100. La radioactivité contenue dans les fractions collectées par le fond du tube est déterminée ; un ARN viral déposé sur un gradient identique donne le repère $37 \mathrm{~S}$. 


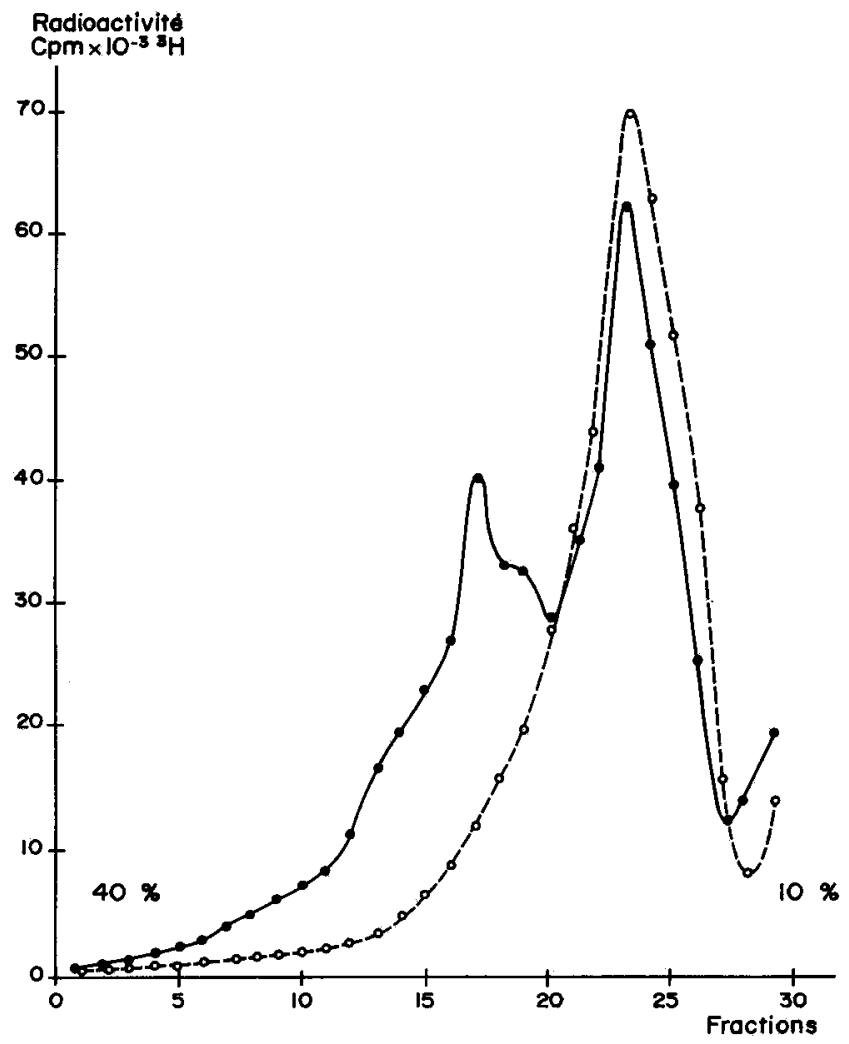

FIG. Io. - Fixation de l'extrait enzymatique sur l'ARN viral en l'absence de nucléotides

-..- - Enzyme + ARN viral radioactif en quantité saturante o . . . . . ARN viral seul

Après $5 \mathrm{mn}$ à température ambiante, le mélange ARN + Enzyme (ou ARN viral) est déposé au sommet d'un gradient de saccharose Io-40 p. Ioo, puis centrifugé $90 \mathrm{mn}$ à $60000 \mathrm{t} / \mathrm{mn}$. En présence d'enzyme une partie de la radioactivité est déplaćé vers le fond du gradient.

- L'enzyme peut se fixer sur l'ARN viral en l'absence de nucléotides. L'enzyme est placée en présence de l'ARN viral radioactif ou en présence d'ARN cellulaires totaux marqués. Comme dans le cas de la réplicase du phage $Q \beta$ (August et al., I968) une analyse en gradient de concentration de saccharose indique qu'une partie de l'ARN viral est déplacée vers le fond du gradient par rapport à la position de l'ARN viral placé seul sur un gradient identique. En revanche, le profil de sédimentation des ARN cellulaires $28 \mathrm{~S}$, I8S, et $4 \mathrm{~S}$ n'est pas modifié (fig. Io et Io bis).

- Enfin à partir d'extraits cytoplasmiques de cellules non infectées, le même traitement ne met pas en évidence d'activité ARN polymérase sensible au modèle viral.

\section{CONCLUSIONS}

Une préparation brute d'ARN polymérase liée au modèle, donc incapable de se fixer sur une autre molécule d'ARN a été extraite des cellules BHK 2 I infectées 
par le virus de la fièvre aphteuse. L'enzyme a été séparée de son modèle viral afin d'étudier l'activité ARN polymérase ARN dépendante.

On sait isoler depuis plusieurs années des préparations brutes (complexes enzyme - ARN matrice) à partir de cellules animales infectées par des virus à ARN (Baltimore, I964; Horton et al., I966 ; Polatnik et ARLINGhaus, I967; GIRARD, I969). En revanche, l'obtention de l'enzyme virale libre est une opération délicate, et ce n'est que très récemment que des résultats positifs ont été publiés (Astier et Cornuet, I969; Garigliano, I970; Watson, r969).

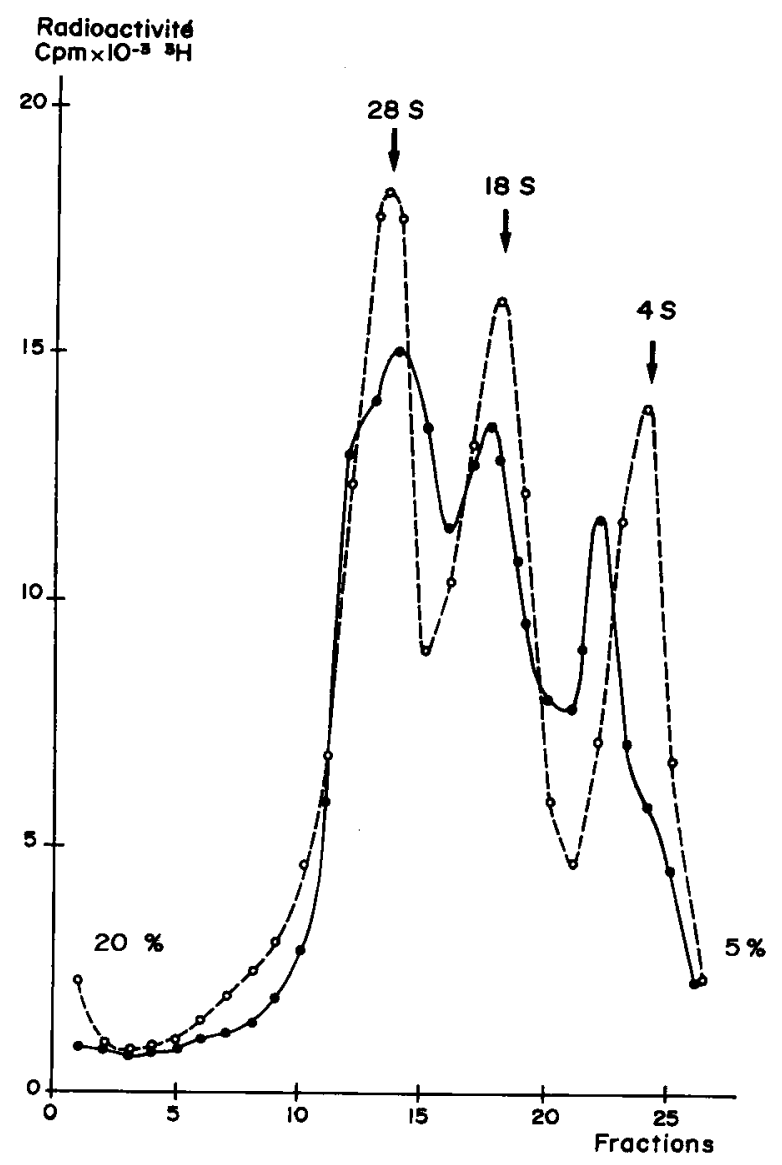

FIG. Io bis. - Fixation de l'extrait enzymatique sur ARN cellulaires totaux en l'absence de nucleotides

- - - - Enzyme + ARN cellulaire radioactif

. . - . ARN cellulaire radioactif seul

Après $5 \mathrm{mn}$ à température ambiante, le mélange ARN + Enzyme (ou les ARN totaux seuls) est déposé au sommet d'un gradient de saccharose 5-20 p. 10o, puis centrifugé $150 \mathrm{mn}$ à 60 ooo $\mathrm{t} / \mathrm{mn}$. En présence d'enzyme, les ARN cellulaires ne sont pas déplacés.

Le développement de ces études in vitro à l'aide de l'enzyme de virus animaux est nécessaire, car la connaissance actuelle du mécanisme de la replication, étape essentielle de la synthèse des virus à ARN reprenait jusqu'à présent les données acquises avec des virus de bactéries. 
Eñn effet, la purification d'une polymérase à partir de bactéries infectées a été menée à bien dès I963 par HaRUNA et coll. et les connaissances du système sont déjà très avancées. Mais la généralisation de ces connaissances n'est pourtant pas sans danger; par exemple la traduction est polycistronique chez les phages, et vraisemblablement monocistronique chez les petits virus animaux à $A R N$.

$\mathrm{L}_{\text {a }}$ purification de 1'ARN polymérase du virus de la fièvre aphteuse à partir des cellules BHK présente des difficultés inhérentes à la qualité du matériel sur lequel nous avons travaillé :

- En premier lieu l'enzyme est fixée sur les membranes ergastoplasmiques et la "solubilisation " par les détergents classiques précédant les essais de purification entraîne une perte d'activité importante (tabl. I). Plusieurs explications sont possibles :

I L L'inhibition traduit une interaction directe des détergents avec la molécule protéique.

$2^{\circ} \mathrm{La}$ " solubilisation " fait passer 1'enzyme d'un milieu apolaire à un milieu polaire, et entraîne une perte de la conformation la plus active de la molécule.

La première hypothèse peut être écartée, car une dialyse de longue durée ne restaure pas l'activité de l'enzyme liée initialement aux membranes.

La deuxième hypothèse doit être vérifiée par addition de phospholipides simples au milieu d'incubation pour permettre à l'enzyme de se retrouver dans un environnement apolaire. De telles expériences ont été réalisées avec succès dans le cas de 1'ATPase sodium-potassium dépendante extraite de la membrane des érythrocytes.

- La présence d'enzymes cellulaires capables de polymériser des nucléotides constitue un autre type de difficulté de notre étude. Pour éliminer ces activités parasites, nous avons pris les précautions suivantes :

$I^{\circ}$ Le milieu d'incubation contient d'une part de l'actinomycine $D$ qui inhibe la transcriptase cellulaire et d'autre part un système régénérateur de triphosphates qui prive la polynucléotide phosphorylase de nucléotides diphosphates.

$2^{\circ}$ Nous utilisons exclusivement les nucléotides $* \mathrm{U}$ ou ${ }^{*} \mathrm{G}-\alpha{ }^{32} \mathrm{P}$ triphosphates pour écarter l'action de la poly A polymérase et de la CCA pyrophosphorylase.

Dans ces conditions les extraits cytoplasmiques de cellules non infectées ne stimulent aucune incorporation de traceur radioactif. On n'observe donc que l'activité enzymatique spécifique de l'infection virale.

Cette activité enzymatique est conditionnée par la présence de 4 bases dans le milieu d'incubation, et nécessite l'addition d'ion $\mathrm{Mg}^{++}$, le vrai substrat de la réaction est le nucléotide portant la molécule de métal ( $\mathrm{Mg}^{++}$- base).

Le résultat de l'activité de l'enzyme brute observée in vitro est la synthèse d'ARN qui possède un coefficient de sédimentation compris entre 30 et $37 \mathrm{~S}$, et qui devrait être identique à l'ARN viral. Malheureusement, le mauvais rendement de la réaction (la vitesse de la réaction diminue rapidement et les nucléases dégradent le matériel nouvellement synthétisé) ne permet pas une investigation plus précise de la nature du produit synthétisé in vitro.

- Une caractérisation plus poussée de l'enzyme brute ne présente guère d'intérêt ; en revanche l'obtention de l'enzyme débarrassée de sa matrice devrait permettre l'étude de la spécificité de la molécule supposée virale, vis-à-vis de différents ARN, susceptibles d'être utilisés comme modèles in vitro. 
- La séparation de l'ARN et de l'enzyme a été acquise par gel-filtration sur agarose $\mathrm{I}, 5 \mathrm{M}$ en force ionique élevée. Cette technique douce est plus fructueuse que la séparation de phase (AUGUST et al., Ig68) ou que la chromatographie sur échangeur d'ions (HARUNA et al., Ig65).

Dans des conditions d'incubation identiques à celles utilisées dans la première partie du travail, la polymérisation des quatre nucléotides est dépendante de l'addition d'ARN viral, de plus la réaction ne semble être amorcée que par l'ARN viral homologue. Cette propriété qui appuie l'hypothèse d'une enzyme virale spécifique est renforcée par l'étude de la fixation de la protéine sur différents ARN en l'absence de nucléotides. En effet, la polymérase se fixe sur l'ARN viral, mais ne reconnaît pas les ARN totaux des cellules BHK.

Le développement de ce travail doit permettre de préciser les résultats obtenus concernant la spécificité de l'enzyme, puis d'étudier in vitro les différentes étapes de la transcription de l'ARN.

$I^{\circ}$ La reconnaissance de l'enzyme pour son ARN homologue.

$2^{\circ}$ La fixation de l'enzyme sur la matrice et l'initiation (site de fixation sur l'ARN, facteurs protéiques éventuellement nécessaires à l'initiation).

$3^{\circ} \mathrm{L}$ a polymérisation et le déplacement de la molécule le long de l'ARN viral.

$4^{\circ}$ L'arrêt de la réaction et la libération de l'enzyme.

Peut-être sera-t-il possible au cours d'une telle étude de mettre en évidence différentes sous-unités dans la molécule et de préciser le rôle éventuel de chacune d'elles, comme cela est actuellement développé dans l'étude de l'ARN polymérase ADN dépendante.

Rę̧u pour publication en mars 1971.

\section{REMERCIEMENTS}

Nous remercions Mme Astier-Manifacier et M. Cornuet qui ont bien voulu suivre notre travail et qui nous ont fait profiter de leur expérience acquise au cours de l'étude de la replicase du virus de la mosaïque jaune du navet.

Ce travail a été réalisé en partie dans le laboratoire de M. CoRnUET, il a ainsi bénéficié d'une aide du Département de Biologie du C. E. A. pour l'achat des nucléotides marqués.

\section{SUMMARY}

\section{NVESTIGATION ON AN RNA POLYMERASE FROM CELLS INFECTED WITH FOOT AND MOUTH DISEASE VIRUS BEFORE AND AFTER ISOLATION FROM THE, VIRAI, RNA}

Évidence is given for the presence of a unique RNA polymerase in virus infected BHK $2 \mathrm{I}$ cells. The enzyme activity was absolutely dependent on the presence of a exogenous viral RNA template. The "Crude polymerase " was initially pepared by ultracentrifugation of cytoplasmic extracts at $120000 \mathrm{~g}$ for $4^{\circ} \mathrm{min}$. This preparation could be stored at $-70^{\circ} \mathrm{C}$ without èloss of activity. Its major in vitro product was viral RNA (37 S). This "crude enzyme " was dependent on the presence of the four ribonucleoside triphosphates and $\mathrm{Mg}^{++}$for full activity and seems similar to the one studied by Arlinghaus and Polatnick. 
In further studies the crude enzyme preparation was purified by action of the ionic strenght followed by gel filtration. The resulting RNA synthetase showed a high degree of template specificity since no significant incorporation was observed with $R_{11}$ or TYMV RNA or with the heteropolymers poly $\mathrm{AC}$ and poly $\mathrm{AG}$. In the absence of nucleotides the enzyme is able to absorb to FMDV RNA but not to cellular RNA. The product formed with the FMDV template by the purified enzyme appears to be polydisperse and, after heat denaturation, is RNase sensitive.

\section{RÉFÉRENCES BIBLIOGRAPHIQUES}

Arlinghaus R B., Polatnick J., 1967. Detergent solubilized RNA polymerase from cells infected with Foot and Mouth Disease Virus. Science, 158, 1320-1332.

Arlinghaus R. B., Polatnick J., I969. In vitro products of a membrane free Foot and Mouth Disease Virus Ribonucleic and Polymerase. Virology, 37, 252-26r.

Asso J., I967. Sélection et etude de mutants froids du virus aphteux. Thèse. Faculté des Sciences, Paris.

Astier-Manifacier, Cornuet P., I969. Purification de la replicase du virus de la mosaïque jaune du navet sous une forme dépendante du modèle. C. R. Acad. Sci. Paris, 269, série D, Io39.

August J. T., Cooper S., SHAPIRo L., ZinDer N., I963. RNA phage induced RNA polymerase. Cold Spring Harbor Symp. Quant. Biol., 28, 95.

August J. T., Banerjee A. K., Eoyang L., Franze de Fernandez M. J., Hori K., Kuo C. H., Rensing M., Shapiro L., I968. Synthesis of Bacteriophage $Q \beta$ RNA. Cold Spring Harbor Symp. Quant. Biol., 38, 73.

Baltimore D., Franklin R. M., I963. A new ribonucleic acid polymerase appearing after Mengovirus infection of L cells. J. Biol. Chem., 238, 3395-3400.

BALTimore D., I964. In vitro synthesis of viral RNA by the poliovirus RNA polymerase. Proc. Nat. Acad. Sci. U.S., 51, 450-456.

COOPER S., ZINDER N. D., I962. The growth of an RNA bacteriophage : the role of DNA synthesis. Virology, 18, 405.

Doi R. H., Spiegelman S., I962. Homology test between the nucleic acid of an RNA virus and the DNA in the host cell. Science, 188, I270.

Garigliano P., Grado C., Fisher S., I969. Partial purification of RNA synthetase obtained from poliovirus-infected HEp-2 cells. Archiv. Gesamte Virusforchung, 28, 269-277.

GIRARD M., 1968. Isolations of Ribonucleic Acids from Mammalian Cells and Animal Virus. Methods in Enzymology: Grossman-Moldave. Nucleic Acids Part A, 12, $58 \mathrm{r}$.

GIRARD M., r969. In vitro synthesis of poliovirus ribonucleic acid : Role of the replicative intermediate. J. Virol., 3, 376-384.

HAag J., Santucci J., Ig62. Culture en série de cellules rénales de porc sensibles au virus de la Fievre Aphteuse. C. R. Acad. Sci. (Paris), 255, I485-1487.

Haruna I., Nozu K., Ohtaka Y., Spiegelman S., I963. "Replicase " induced by and selective for a viral RNA : isolation and properties. Proc. Nat. Acad. Sci. U. S., 50, 905-9II.

Haruna I., Spiegelman S., r965. Specific template requirements of RNA replicases. Proc. Nat. Acad. Sci. U.S., 54, 579-587.

Horton E., Liv S., Martin E., Work T. S., I966. Properties of a virus induced RNA polymerase in ascites cells infected with encephalomyocarditis virus. J. Mol. Biol., 15, 62-67.

Lowry O. H., Rosebrough N. J., FARR A. L., Randali R. J., I95I. Protein measurement with the Folin phenol reagent. J. Biol. Chem., 188, 265-275.

Penman S., Becker Y., Darnell J. E., I964. A cytoplasmic structure involved in the synthesis and assembly of Poliovirus components. J. Mol. Biol., 8, 54r.

Spiegelman S., Pace N. R., Mills D. R., Levisohn R., Eikhom T. S., Taylor M. M., Peterson T. L., Bishop D. H. L., 1968. The mechanism of RNA replication. Cold Spring Harbor Symp. Quant. Biol., 38, 73.

Watson K. F., Beaudreau G. S., I969. Isolation of RNA, Dependant RNA Polymerase from Virus Infected Myeloblasts. Biochem. Biophys. Res. Comm., 37, 6, 925.

WeissmanN C., Simon L., OchoA S., r963. Induction by an phage of a enzyme catalyzing the incorporation of ribonucleotides into ribonucleic acid. Proc. Nat. Acad. Sci. U.S., 49, 407-414.

Weissmand C., Feix G., r966. Replication of Viral RNA. XI. Synthesis of viral " minus " strands in vitro. Proc. Nat. Acad. Sci. U.S., 55, 1264.

Weissmand C., Feix G., SloR H., I968. In vitro synthesis of phage RNA : the nature of the intermediates. Cold Spring Harbor Symp. Quant. Biol., 33, 73. 